\title{
Microbial succession and changes in carbon and nitrogen during decomposition of leaf litters of Tephrosia candida (Roxb.) DC. and Oryza sativa L. under shifting cultivation in Mizoram, northeast India
}

\author{
Shrayosee Ghosh \\ Department of Forestry, Mizoram University, Aizawl-796004 (Mizoram), India \\ Shri Kant Tripathi* \\ Department of Forestry, Mizoram University, Aizawl-796004 (Mizoram), India \\ *Corresponding author. Email: sk_tripathi@rediffmail.com
}

\section{Article Info}

https://doi.org/10.31018/

jans.v13i3.2855

Received: July 22, 2021

Revised: September 2, 2021

Accepted: September 5, 2021

\section{How to Cite}

Ghosh, S. and Tripathi, S. K. (2021). Microbial succession and changes in carbon and nitrogen during decomposition of leaf litters of Tephrosia candida (Roxb.) DC. and Oryza sativa L. under shifting cultivation in Mizoram, northeast India. Journal of Applied and Natural Science, 13(3), 1032 - 1040. https://doi.org/10.31018/jans.v13i3.2855

\begin{abstract}
The present study aims to understand microbial succession and dynamics of dry matter, carbon and nitrogen during the decomposition of leaf litters of Tephrosia candida (Roxb.) DC. and Oryza sativa L. in two fallow lands (FL) of 3 years (FL-3) and 8 years (FL-8) following shifting cultivation in Mizoram. A total of 64 microorganisms were isolated from two leaf litters by serial dilution method, out of which 13 microbes were identified as decomposers as they exhibited a positive response towards the enzyme activity. Among these 13 microorganisms, 4 (SKT 02, SKT 05, SKT 09 and SKT 020) were bacteria (Streptobacillus sp. and Bacillus sp.), 5 (SKT 033, SKT 034, SKT 035, SKT 040 and SKT045) were fungi (Microsporum sp., Rhizopus sp. and Aspergillus sp.) and 4 (SKT 030, SKT 052, SKT 053 and SKT 060) were actinomycetes (Streptomycetes sp.). T. candida leaf litter possessed low initial Carbon/Nitrogen (8.77) and Lignin/Nitrogen ratio (2.29) and considered a high-quality resource exhibiting higher decomposition rate. Mass loss of carbon and nitrogen $(\sim 40-80 \%)$ was maximum during the initial two months, which slowed down in the later period of decomposition. It was concluded that the number of bacteria, fungi and actinomycetes regulate organic matter and nutrient dynamics in the soil through various enzymatic actions on high- and low-quality litters. The combination of $O$. sativa and $T$. candida litter is recommended to manage soil fertility in shifting cultivation of Mizoram, Northeast India.
\end{abstract}

Keywords: Carbon- Nitrogen dynamics, Decay rate, Decomposition, Fertility, Microorganisms

\section{INTRODUCTION}

Mizoram is one of the seven states of Northeast India with undulating topography dominated by tribal populations. The majority of the people are involved in shifting cultivation or jhum for their livelihood. Previously, this practice of cultivation was fairly productive due to recuperated soil fertility through plant regeneration under prolonged fallow periods (20-30 years). However, in recent years the length of the fallow period decreased due to increasing population that lead to a decrease in soil fertility and crop productivity (Grogan et al., 2012), and raised concern among the poor farmers for their livelihood. Thus, there is a need to revitalize this agri- cultural system to be ecologically beneficial by understanding the decomposition dynamics of locally accessible litters. Litter decomposition affects nutrient cycle and carbon storage in the ecosystem (Hobbie et al., 2012), which is highly governed by litter substrate quality and microbial community composition during litter decomposition (Swift et al., 1979). Lignin/N and $\mathrm{C} / \mathrm{N}$ ratios of litters have been widely used to predict decay rate in different ecosystems (Taylor et al., 1989, Tripathi et al 1992a \& b, Wapongnunsang et al 2017, Lalnunzira and Tripathi 2018). The litter N concentration and soil $\mathrm{N}$ availability also have important impacts on litter decomposition ( $\mathrm{Li}$ et al., 2017). Generally, decomposition rates are greater when the initial $\mathrm{N}$ 
concentration is high and the $\mathrm{C}: \mathrm{N}$ ratio is low (Cornwell et al., 2008).

Soil inhabits a diverse group of microorganisms (mainly bacteria, fungi, and actinomycetes) responsible for the decomposition of organic matter (Manpoong et al., 2020). The biodegradation of organic matter occurs by the concentrated action of various microorganisms which produce a series of enzymes that contribute to the decomposition process (Pérez et al., 2002, Lalnunzira and Tripathi 2018). During decomposition, litter rapidly loses easily soluble compounds, including starch, amino acids and sugar, due to leaching, microbial activity and soil fauna attack (Singh and Tripathi, 2020). The bacterial population is most dominant, whereas actinomycetes are one-tenth in number, but the fungal population is dominant in uninterrupted soil (Hoorman, 2010). Decomposing litters revealed a successional shift from fast-growing to specialized bacteria and fungi (Herzog et al., 2019). Bacteria play an important role in the early stage of decomposition, and fungi and actinomycetes in the later stages of decomposition (Singh and Tripathi, 2020). Fungi are considered to be the major contributors to decomposition due to their ability to produce specific enzymes and the possibility to access new substrates through their hyphae (Bani et al., 2018). Actinomycetes have been reported to promote a slow breakdown of humates (Abbott and Murphy, 2003). Leaf litter accounted for approximately $81 \%$ of annual plant litter production (Mason, 1977; Scarascia- Mugnozza et al., 2000). Inputs of litter from the plants play an important role in the soil microorganisms and fertility levels under shifting cultivation areas as they are the main source of nutrients to the crop plants through the microbial transformation of litters (Momin et al., 2021 and Hauchhum and Tripathi, 2019). Therefore, the quality and the quantity of litter inputs from various plants significantly affect the interaction of the microbial communities on the litter and ultimately affect the ability of the soil to provide available nutrients to the crop plants (Lalnunzira and Tripathi, 2018). Tephrosia candida, a bushy species, forms dense vegetation cover and thus produces high biomass, and additionally, add $\mathrm{N}$ to the soil through fixation (Nguyen and Thai, 1993 and Wapongnungsang et al., 2017). The species have been reported to be widely used in the rehabilitation of degraded land through fixing atmospheric nitrogen, controlling soil erosion and increasing the levels of soil nutrients by adding organic matter and nutrients through the process of decomposition (Wapongnun gsang et al., 2017). Oryza sativa $L$ is the major crop plant under shifting cultivation in NE region and after the harvesting of rice, the whole plant parts are left on the ground to decompose and add nutrients for the second-year cropping. The 0 . sativa litter release $15.4 \%$ to $38.4 \%$ of total organic carbon in soil through decompo- sition (Villegas -Pangga et al., 2000). Keeping this in mind, this paper aims to provide comprehensive information on microbial changes during the decomposing of $T$. candida and $O$. sativa leaf litter and the successive changes in $\mathrm{C}$ and $\mathrm{N}$ release from these litters to the soil under shifting cultivation field in Mizoram, northeast India.

\section{MATERIALS AND METHODS}

\section{Site description}

The present study was carried out in Tanhril (Fig. 1), Mizoram on shifting cultivation fields i.e., on two fallow ages of 3 years (FL-3; 23⒊ $39^{\prime \prime} \mathrm{N}, 92^{\circ} 31^{\prime} 48^{\prime \prime}-92^{\circ}$ $\left.33^{\prime} 24^{\prime \prime} \mathrm{E}\right)$ and 8 years (FL-8; $23^{\circ} 43^{\prime} 55^{\prime \prime}-23^{\circ} 44^{\prime} 48^{\prime \prime} \mathrm{N}$, $\left.92^{\circ} 38^{\prime} 43^{\prime \prime}-92^{\circ} 40^{\prime} 4^{\prime \prime} \mathrm{E}\right)$. Tanhril is located about $15 \mathrm{~km}$ away from Aizawl city. The temperature of the area is sub-tropical $\left(20-30^{\circ} \mathrm{C}\right.$ in summer and $11-21^{\circ} \mathrm{C}$ in winter) with considerable seasonal variations. The total annual rainfall ranged $\sim 2250-3200 \mathrm{~mm}$ from 2017-2020 and relative humidity was over $70 \%$ throughout the year (Anonymus, 2020).

\section{Experimental design}

$T$. candida and $O$. sativa leaf litters were collected from the field, air dried and $10 \mathrm{~g}$ of each litter type were enclosed in nylon net bags measuring $20 \mathrm{~cm} \times 20 \mathrm{~cm}$ with $2 \mathrm{~mm}$ mesh size. Leaf litter bags of $T$. candida, $O$. sativa alone and in combinations ( $T$. candida $+O$. sativa in equal proportions) were made. A total of 50 litter bags of each litter type were placed randomly on soil of two fallow lands (FL-3 and FL-8). Every month four litter bags of each liter type were retrieved for one year so a total 12 recoveries were made. One bag was used for microbial isolation and rest three bags were cleaned,

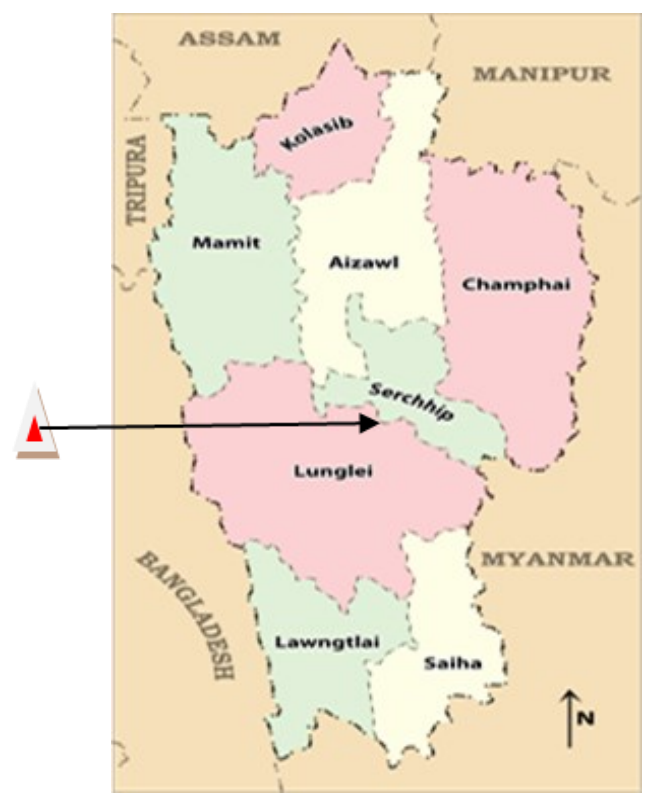

Fig. 1. Mizoram map showing the study area. 
leaf litters were dried and powdered for determining nutrient changes in litters during decomposition.

\section{Isolation of microbes}

Microbes were isolated from the decomposing litters within 24 hours of collection by serial dilution plate method. $1 \mathrm{~g}$ of crushed litter sample was dissolved in $10 \mathrm{ml}$ of $0.9 \% \mathrm{NaCl}$ solution and serially diluted in saline solution up to $10^{-6}$ (Martin, 1950). An aliquot of $0.1 \mathrm{ml}$ of each dilution was taken and transferred to a separate Nutrient Agar (NA) plate, Potato Dextrose Agar (PDA) plate and Starch Casein Agar (SCA) plate and spread with L-spreader carefully which was then incubated at $37^{\circ} \mathrm{C}, 24^{\circ} \mathrm{C}$ and $28^{\circ} \mathrm{C}$ for 24 hours, 48 hours and 4 weeks for bacteria, fungi and actinomycetes, respectively.

\section{Determination of microbial enzyme activity}

Five enzyme tests of isolated microbes were carried out during the study. Catalase, cellulase, amylase, protease and lipase test (Kumar et al., 2015) were done with all three microbial types. Microbes showing positive enzyme activity were highly responsible for decomposition.

\section{Characterization of microorganisms}

13 microbial isolates (SKT 02, SKT 05, SKT 09, SKT 020, SKT 033, SKT 034, SKT 035, SKT 040, SKT 045, SKT 030, SKT 052, SKT 053, SKT 060) showing positive enzyme activity were purified. Purified isolates of bacteria and actinomycetes were identified up to genus level according to Bergey's Manual of Determinative Bacteriology (Bergey and Holt, 2000) and fungi according to Gliman's Manual of Soil Fungi (Gilman 1957). The isolation and identification were made through micro-morphological observation and enzyme activity, respectively. Visual observation included both morpho- logical and microscopical characteristics (like aerial mycelia, colony color, spore morphology etc.) were taken into consideration.

\section{Analysis of carbon, nitrogen and lignin}

Dried and powdered litter materials were used for analysis. The carbon content of the litter was estimated by loss on ignition method (Mcbrayer and Cromack, 1980), total Nitrogen by Micro Kjeldahl methods (Jackson, 1973) and lignin by acid detergent fiber method (Van Soest and Wine, 1968).

\section{Calculation and statistical analysis}

The relative decomposition rate (RDR) was calculated by using formula:

$\operatorname{RDR}\left(\mathrm{g} \mathrm{g}^{-1}\right.$ day $\left.^{-1}\right)=\ln \left(\mathrm{W}_{\mathrm{t}}-\mathrm{W}_{0}\right) /\left(\mathrm{t}_{1}-\mathrm{t}_{0}\right) \quad$.....Eq. 1 Where $W_{0}=$ mass of litter present at time $t_{0}, W_{t}=$ mass of litter at time $t_{1}$, and $t_{1}-t_{0}=$ sampling interval (days).

The daily instantaneous decayed constant $(k)$ of litter was calculated through the negative exponential decay model of Olson (1963):

$W_{t} / W_{0}=\exp ^{(-k t)}$

Where $\mathrm{W}_{0}=$ initial mass of the litter, and $\mathrm{W}_{\mathrm{t}}=$ mass remaining after time t.

As suggested by Olson (1963), the time required for $50 \%$ mass loss was calculated as

$t_{50}=0.693 / k$ and for $95 \%$ mass loss as $t_{95}=3 / k$.

\section{RESULTS AND DISCUSSION}

A total 64 microbes were isolated from three different decomposing litters ( $T$. candida, O. sativa and $T$. candida + O. sativa) on two fallow lands (FL-3 and FL-8) following shifting cultivation in Mizoram. Among them, 13 microbes showed positive enzyme activity (Table 1). The highest positive response to catalase activity was recorded in strains (SKT 033, SKT034, SKT 040, SKT

Table 1. In vitro screening of enzyme activity of isolates.

\begin{tabular}{llllll}
\hline Isolate Code & Catalase & Cellulase & Amylase & Protease & Lipase \\
\hline SKT 02 & + & + & + & +++ & - \\
SKT 05 & + & + & + & +++ & - \\
SKT 09 & ++ & + & + & +++ & - \\
SKT 020 & + & + & + & + & - \\
SKT 033 & +++ & + & + & - & - \\
SKT 034 & +++ & + & - & + & - \\
SKT 035 & + & + & + & ++ & - \\
SKT 040 & +++ & - & + & + & - \\
SKT 045 & +++ & + & + & ++ & - \\
SKT 030 & ++ & - & + & ++ & - \\
SKT 052 & +++ & + & - & ++ & - \\
SKT 053 & + & + & - & + & - \\
SKT 060 & + & + & + & + & \\
\hline
\end{tabular}

,,,-++++++ indicative of nil, low, medium and high activity 
045 and SKT 052) as they produced vigorous effervescence on the addition of $3 \%$ hydrogen peroxide (Fig.2.A). However, a negative response was noted against cellulase activity in strains (SKT 040 and SKT 030), and against amylase activity in strains (SKT 034, SKT 052 and SKT 053) and protease activity in SKT 033. SKT 02, SKT 05 and SKT 09 were found to have more protease activity than other strains as they were capable of producing a large clear zone $(1.5 \mathrm{~cm}$ in diameter) on skim milk agar plate around colonies (Fig.2.B). On the other hand, no lipase activity was noticed on these 13 strains. Out of 13 strains, $31 \%$ were bacteria, 38\%fungi and $31 \%$ were actinomycetes. On NA plate, all the bacterial colonies were able to grow well in 24 hours. Their colony nature was maximum irregular in shape, dark to light cream in color and colony diameter was between $0.5 \mathrm{~cm}-1.5 \mathrm{~cm}$. However, fungal colonies took 5-7 days to grow on PDA plate, some of the colonies showed colored pigment with $0.1 \mathrm{~cm}$ $2 \mathrm{~cm}$ colony diameter and actinomycetal colonies took 2 - 9 days to grow in SCA plate and maximum colonies were powdery in nature. According to the colony morphology and microscopic view (Fig. $2 \mathrm{C}$ and D), 13 isolated strains were identified up to genus level (Table 2). In the present study, most of the bacterial genus was Streptobacillus sp. followed by Bacillus sp. Similar bacterial strains were also isolated by Debi \& Prakash (2017) from rhizospheric soil of northeast India. Previous enzymatic studies on these two bacterial genera
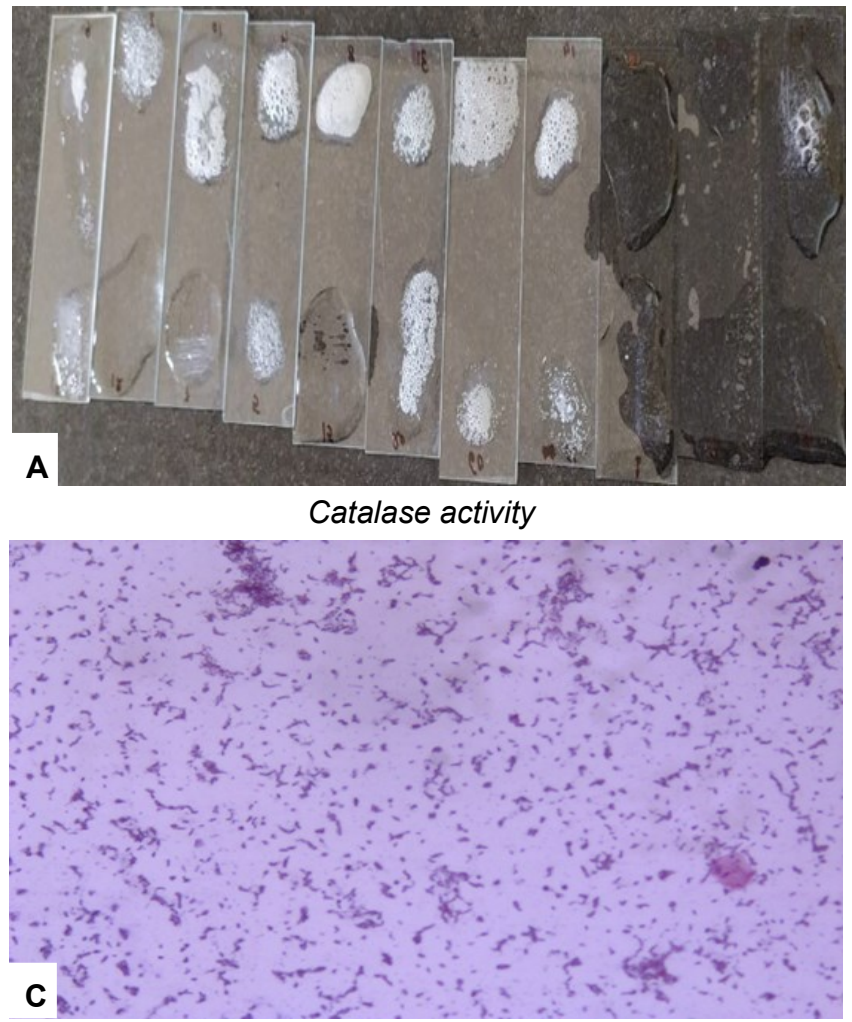

Streptobacillus sp.
(Streptobacillus sp. and Bacillus sp.) displayed positive activity towards cellulase (Sethi et al., 2013 and Rajagopal et al., 2007), catalase (Babiker et al., 2017 and Eisenberg et al., 2015) and protease (Pant et al., 2015 and Eisenberg et al., 2015) test. These enzymes are active during the course of decomposition process. Some soil fungi are responsible for the decomposition of plant litters and releasing nutrients to the soil for plant growth (Raaijmakers et al., 2009), because they are responsible for decomposing cellulose and lignin through enzymatic actions (Hoorman, 2011). The present study found 3 different genera of fungi namelyMicrosporum sp., Rhizopus sp. and Aspergillus sp. from three different litter types ( $T$. candida, $O$. sativa and $T$. candida + O. sativa). Parallel fungal findings were also recorded by Giudice et al. (2012) and Debi \& Prakash (2017) from the soil, showing proteolytic enzyme activities that further breakdown the recalcitrant compounds of leaf litters and results in decomposition. Actinomycetes are highly distributed in different habitats and ecosystems (Ghorbani-Nasrabadi et al., 2013). A previous study reported salt tolerant activity in Streptomycetes $s p$. obtained from shifting cultivated area of Mizoram (Momin and Tripathi, 2019). Therefore, the presence of this species as decomposing actinomycetal strain indicated the salt tolerance ability in the shifting cultivation. Additionally, actinomycetes are also known to have cellulose-degrading properties (Eida et al., 2012).
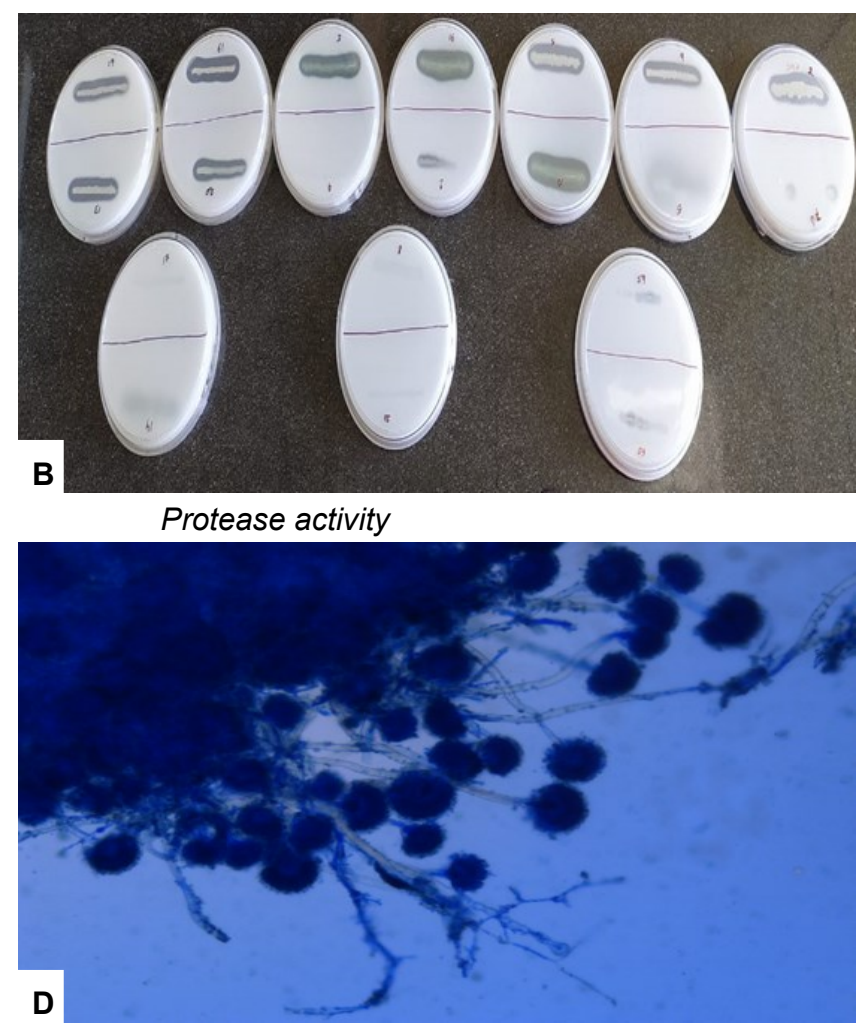

Aspergillus sp.

Fig. 2. Showing enzyme activities $(A-B)$ and microscopic view (C-D) of isolates. 
Table 2. Morphological characterization of 13 isolated microbial strains of Mizoram. AM and SM-representatives of Aerial Mycelium and Substrate Mycelium.

\begin{tabular}{|c|c|c|c|c|c|c|c|c|c|}
\hline \multirow[t]{2}{*}{$\begin{array}{l}\text { Isolate } \\
\text { code }\end{array}$} & \multicolumn{3}{|c|}{ Nature of colony } & \multicolumn{2}{|c|}{ Color of colony } & \multirow[t]{2}{*}{$\begin{array}{l}\text { Days of } \\
\text { growth }\end{array}$} & \multirow[t]{2}{*}{ Media } & \multirow[t]{2}{*}{$\begin{array}{l}\text { Identified } \\
\text { microbe }\end{array}$} & \multirow[t]{2}{*}{ Litter type } \\
\hline & Forms & Elevation & Margin & AM & SM & & & & \\
\hline SKT 02 & Irregular & Umbonate & Undulate & $\begin{array}{l}\text { Dark cream, } \\
\text { rough, colony } \\
\text { with } 0.8 \mathrm{~cm} \text { in } \\
\text { dia. }\end{array}$ & $\begin{array}{l}\text { Light } \\
\text { cream }\end{array}$ & 1 day & NA & $\begin{array}{l}\text { Streptobacillus } \\
\text { sp. } \\
\text { (Gram -ve) }\end{array}$ & T.candida \\
\hline SKT 05 & Irregular & Raised & Undulate & $\begin{array}{l}\text { Light cream, } \\
\text { rough, colony } \\
\text { with } 0.5 \mathrm{~cm} \text { in } \\
\text { dia. }\end{array}$ & $\begin{array}{l}\text { Light } \\
\text { cream }\end{array}$ & 1 day & NA & $\begin{array}{l}\text { Streptobacillus } \\
\text { sp. } \\
\text { (Gram -ve) }\end{array}$ & $\begin{array}{l}\text { T.candida } \\
\text { and } \\
\text { O.sativa }\end{array}$ \\
\hline SKT 09 & Circular & Flat & Undulate & $\begin{array}{l}\text { Dark cream, } \\
\text { rough, colony } \\
\text { with } 1.4 \mathrm{~cm} \text { in } \\
\text { dia. }\end{array}$ & Cream & 1 day & NA & $\begin{array}{l}\text { Streptobacillus } \\
\text { sp. } \\
\text { (Gram -ve) }\end{array}$ & $\begin{array}{l}\text { T.candida + } \\
\text { O.sativa }\end{array}$ \\
\hline $\begin{array}{l}\text { SKT } \\
020\end{array}$ & Irregular & Raised & Undulate & $\begin{array}{l}\text { Dark cream, } \\
\text { smooth, colo- } \\
\text { ny with } 1 \mathrm{~cm} \\
\text { in dia. }\end{array}$ & Cream & 1 day & NA & $\begin{array}{l}\text { Bacillus sp. } \\
\text { (Gram +ve) }\end{array}$ & O.sativa \\
\hline $\begin{array}{l}\text { SKT } \\
033\end{array}$ & Circular & Raised & Entire & $\begin{array}{l}\text { Greenish } \\
\text { grey, rough, } \\
\text { colony with } \\
0.1 \mathrm{~cm} \text { in dia. }\end{array}$ & White & 5 days & PDA & Microsporum sp. & T.candida \\
\hline $\begin{array}{l}\text { SKT } \\
034\end{array}$ & Circular & Umbonate & Filiform & $\begin{array}{l}\text { White, wrin- } \\
\text { kled, colony } \\
\text { with } 2 \mathrm{~cm} \text { in } \\
\text { dia. }\end{array}$ & White & 5days & PDA & Rhizopus sp. & T.candida \\
\hline $\begin{array}{l}\text { SKT } \\
035\end{array}$ & Circular & Umbonate & Filiform & $\begin{array}{l}\text { White margin } \\
\text { and light yel- } \\
\text { low in center, } \\
\text { wrinkled, } \\
\text { colony with } \\
1.3 \mathrm{~cm} \text { in dia. }\end{array}$ & White & 5 days & PDA & Rhizopus sp. & $\begin{array}{l}\text { T.candida + } \\
\text { O.sativa } \\
\text { and } \\
\text { O.sativa }\end{array}$ \\
\hline $\begin{array}{l}\text { SKT } \\
040\end{array}$ & Circular & Undulate & Entire & $\begin{array}{l}\text { White, } \\
\text { Rough, colo- } \\
\text { ny with } 2 \mathrm{~cm} \\
\text { in dia. }\end{array}$ & Cream & 7 days & PDA & Aspergillus sp. & T.candida \\
\hline $\begin{array}{l}\text { SKT } \\
045\end{array}$ & Irregular & Umbonate & Curled & $\begin{array}{l}\text { White, rough, } \\
\text { colony with } \\
1.5 \mathrm{~cm} \text { in dia. }\end{array}$ & White & 2 days & PDA & Aspergillus sp. & $\begin{array}{l}\text { T.candida + } \\
\text { O.sativa }\end{array}$ \\
\hline $\begin{array}{l}\text { SKT } \\
030\end{array}$ & Irregular & Raised & Curled & $\begin{array}{l}\text { White, rough, } \\
\text { colony with } \\
0.3 \mathrm{~cm} \text { in dia. }\end{array}$ & $\begin{array}{l}\text { Light } \\
\text { cream }\end{array}$ & 3 days & SCA & $\begin{array}{l}\text { Streptomycetes } \\
\text { sp. } \\
(\text { Gram +ve) }\end{array}$ & $\begin{array}{l}\text { T.candida + } \\
\text { O.sativa }\end{array}$ \\
\hline $\begin{array}{l}\text { SKT } \\
052\end{array}$ & Irregular & Flat & Undulate & $\begin{array}{l}\text { Light grey, } \\
\text { powdery, } \\
\text { colony with } \\
0.2 \mathrm{~cm} \text { in dia. }\end{array}$ & $\begin{array}{l}\text { Light } \\
\text { cream }\end{array}$ & 2 days & SCA & $\begin{array}{l}\text { Streptomycetes } \\
\text { sp. } \\
(\text { Gram +ve) }\end{array}$ & O.sativa \\
\hline $\begin{array}{l}\text { SKT } \\
053\end{array}$ & Irregular & Flat & Undulate & $\begin{array}{l}\text { White, pow- } \\
\text { dery, colony } \\
\text { with } 0.3 \mathrm{~cm} \text { in } \\
\text { dia. }\end{array}$ & $\begin{array}{l}\text { Light } \\
\text { orange }\end{array}$ & 2 days & SCA & $\begin{array}{l}\text { Streptomycetes } \\
\text { sp. } \\
(\text { Gram +ve) }\end{array}$ & O.sativa \\
\hline $\begin{array}{l}\text { SKT } \\
060\end{array}$ & Irregular & Flat & Undulate & $\begin{array}{l}\text { Light grey, } \\
\text { powdery, } \\
\text { colony with } \\
0.5 \mathrm{~cm} \text { in dia. }\end{array}$ & Black & 9 days & SCA & $\begin{array}{l}\text { Streptomycetes } \\
\text { sp. } \\
(\text { Gram +ve) }\end{array}$ & $\begin{array}{l}\text { T.candida + } \\
\text { O.sativa }\end{array}$ \\
\hline
\end{tabular}


Table 3. Decomposition rate, daily decay rate $(k)$ nd time required for decomposition (t $50 \%$, $t 95 \%$ mass loss) of leaf litters of $T$. candida, O.sativa and T. candida + O.sativa in different fallow periods.

\begin{tabular}{llllll}
\hline Fallow period & Litter type & $\begin{array}{l}\text { Mass remaining } \\
\text { (\% initial) } \mathbf{3 6 5} \text { days }\end{array}$ & $\begin{array}{l}\text { Daily decay } \\
\text { rate } \mathbf{( k )}\end{array}$ & $\mathbf{t}_{\mathbf{5 0}}$ (days) & $\mathbf{t}_{\mathbf{9 5}}$ (days) \\
\hline 3 years & T.candida & 9.33 & 0.006001 & 115 & 500 \\
& O.sativa & 12.97 & 0.00587 & 118 & 511 \\
& T.candida + O.sativa & 11.83 & 0.005933 & 116 & 505 \\
8 years & T.candida & 0 & 0.006116 & 113 & 491 \\
& O.sativa & 0 & 0.00608 & 114 & 494 \\
& T.candida + O.sativa & 7.17 & 0.006074 & 114 & 493 \\
\hline
\end{tabular}

Table 4. Initial chemical composition of different leaf litters.

\begin{tabular}{llllll}
\hline Leaf litter type & Carbon (\%) & Nitrogen (\%) & Lignin (\%) & C/N ratio & Lignin/N ratio \\
\hline T.candida & $36.69 \pm 0.01$ & $4.14 \pm 0.01$ & $9.63 \pm 0.02$ & 8.84 & 2.32 \\
O.sativa & $41.22 \pm 0.4$ & $1.52 \pm 0.01$ & $21.89 \pm 0.02$ & 27.12 & 14.4 \\
T.candida + O.sativa & $41.55 \pm 0.01$ & $2.55 \pm 0.04$ & $18.23 \pm 0.02$ & 16.29 & 7.15 \\
\hline
\end{tabular}

Values are means $\pm S E(n=4)$

The decomposition rate of leaf litters of $T$. candida, $O$. sativa and $T$. candida $+O$. sativa showed a similar pattern in both fallow fields (FL-3 and FL-8). The rate of decomposition was faster in FL-8 ( $k=0.006074$ 0.006116 ) as compared to FL-3 ( $\mathrm{k}=0.00587$ $0.006001)$. Mass loss ( 80\%) was more rapid for $T$. candida in the initial months. Mass loss was faster in FL-8 as compared to FL-3 ). In general, the mass loss was considerably high during the initial months than the later months. The significant differences in mass loss among litter types were not clear in FL-8, but the differences in the mass were evident in the later stages of different litter types (Fig. 3). Similar findings were reported in litter decomposition of two species of Tephrosia sp. in Malawi, Africa (Munthali et al., 2015). Rapid mass loss in the initial months may be related to the

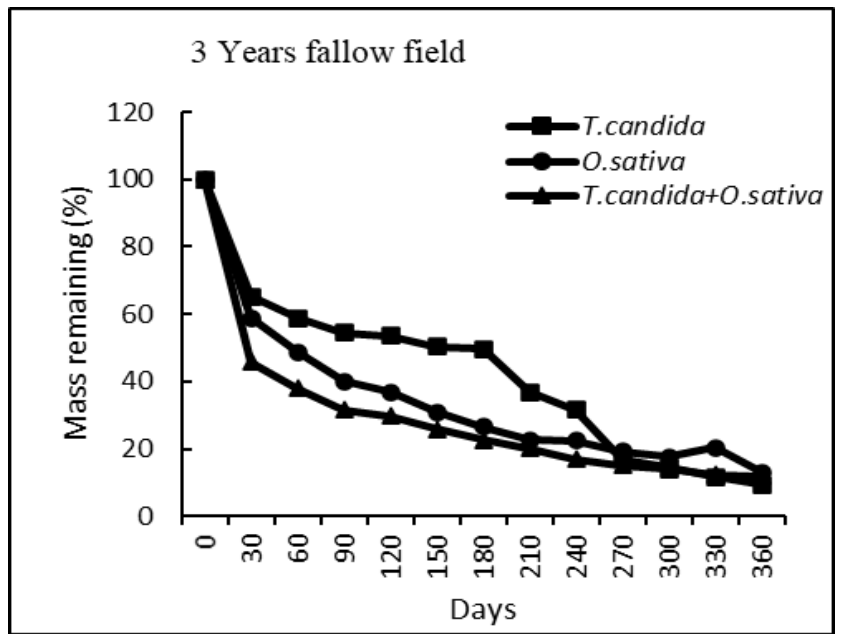

release of higher concentrations of liable substances in the initial period of decomposition (Wang et al., 2004). The daily instantaneous decay constant $(k)$, number of days required for $50 \%\left(t_{50}\right)$ and $95 \%\left(t_{95}\right)$ decomposition of all leaf litter types were in order: T.candida> T.candida + O.sativa> O. sativa (Table 3).

Variations in the initial concentrations of $\mathrm{C}, \mathrm{N}$ and Lignin as reflected by $\mathrm{C} / \mathrm{N}$ and Lignin/N ratio (Table 4 ) are important determinants of decomposition in the litter (Tripathi and Singh 1992 a \& b; Wapondnungsang et al., 2017; Lalnunzira and Tripathi, 2018). The $C$ release from the leaf litters followed a pattern similar to that of mass loss with rapid mass loss at the beginning, which slowed down in the latter part of decomposition (Fig. 4). $\mathrm{N}$ mass loss was also rapid during the initial months. Higher initial $\mathrm{N}$ content and lower $\mathrm{C} / \mathrm{N}$ ratio in leaf litters

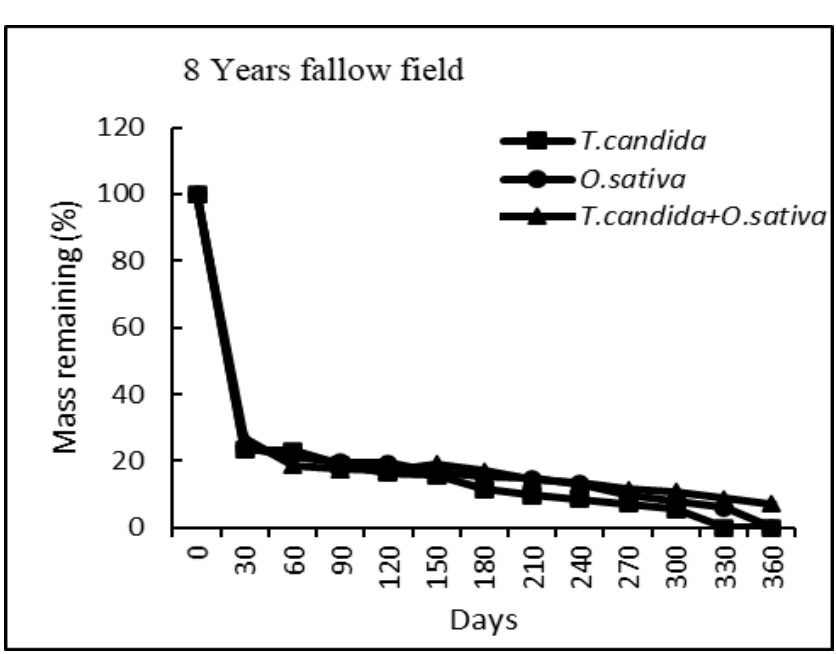

Fig.3. Mass remaining of different leaf litters in two fallow lands. 
Ghosh, S. and Tripathi, S. K. / J. Appl. \& Nat. Sci. 13(3), 1032 - 1040 (2021)
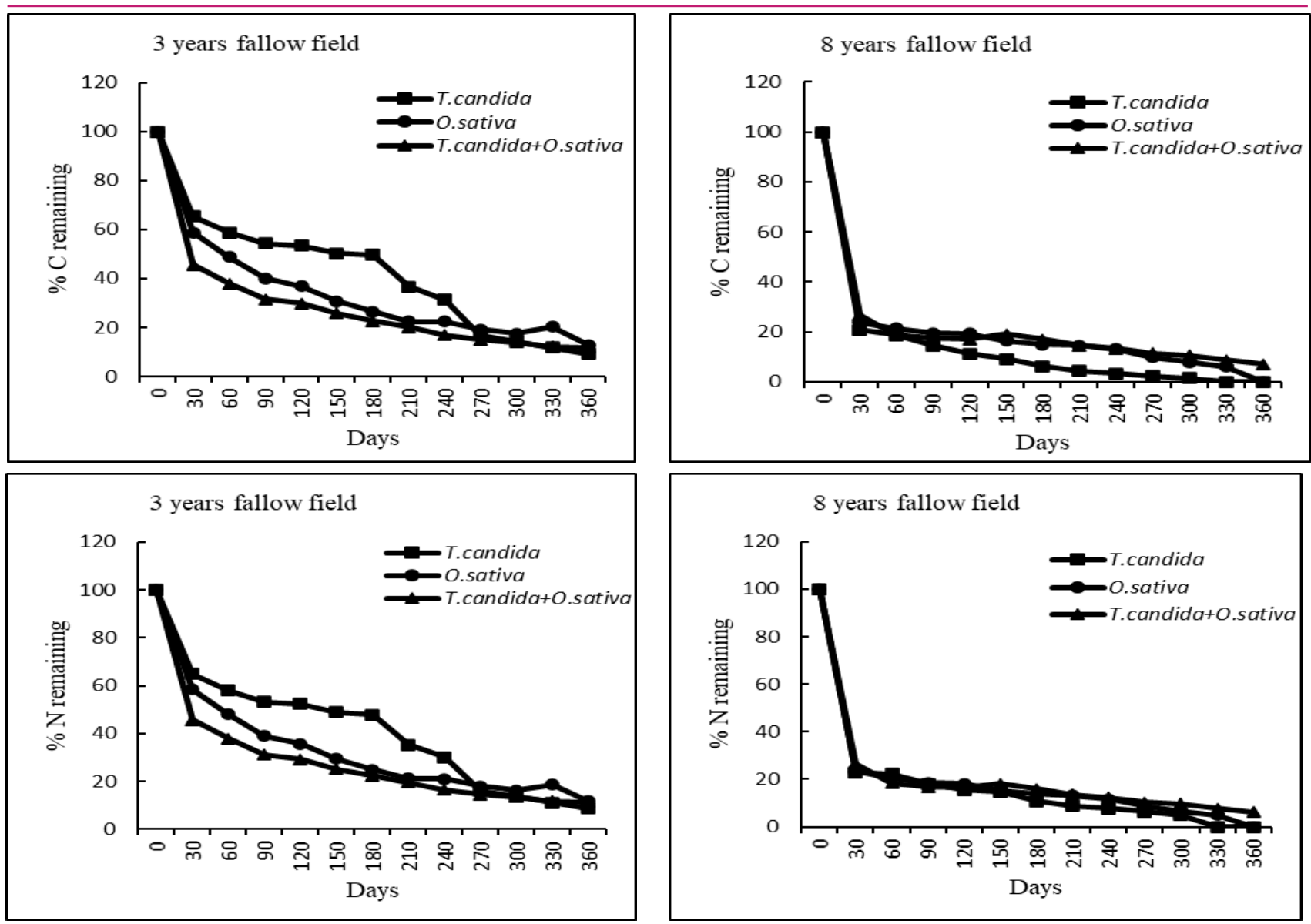

Fig. 4. Carbon $(C)$ and Nitrogen $(N)$ release pattern from leaf litters of T.candida, O.sativa and T.candida+O.sativa in 3 years and 8 years fallow land.

(Table 4) have been reported to favour the rapid release of $\mathrm{N}$ during the initial stages of decomposition (Hoorman, 2010). According to Quideau et al. (2005), leaf litters with higher $\mathrm{N}$ content showed a faster decay rate in Chaparral ecosystem in Southern California. The percentage of $\mathrm{N}$ mass remaining at the end of the sampling period (i.e. 1 year) for different leaf litters varied from $0-15 \%$, with the lowest in $T$. candida (FL $3-$ $8.72 \%, \mathrm{FL} 8-0$ ) followed by $T$. candida + O. sativa (FL $3-11.28 \%$, FL $8-0$ ) and O. sativa (FL $3-12 \%$, FL 8 -0 ). The high initial $\mathrm{C} / \mathrm{N}$ ratio in $\mathrm{O}$. sativa may partially be responsible for the slow rate of decomposition and nutrient release in the soil (Bauder, 2000 and Fosu et al., 2007). The higher mass loss in longer fallow than shorter fallow may be due to a higher rate of decomposition that may result from increased microbes and their activity because the higher organic matter present may act as a source of energy for the decomposers, as reported by Wapongnungsang et al., (2017).

\section{Conclusion}

This study concluded that different microbes like bacteria, fungi, and actinomycetes present on various highand low-quality resources showed two or more enzy- matic activities responsible for soil organic decomposition and nutrient release. The combination of $O$. sativa and $T$. candida litter is recommended for soil fertility management in shifting cultivation of Mizoram, Northeast India. Further, inoculation of isolated microbes can accelerate the process of decomposition and nutrient release in shorter fallow land that may further enhance the productivity of shorter jhum fields.

\section{ACKNOWLEDGEMENTS}

The authors are thankful to the Department of Forestry, Mizoram University, Mizoram, for extending the facilities.

\section{Conflict of interest}

The authors declare that they have no conflict of interest.

\section{REFERENCES}

1. Abbott, L. K., \& Murphy, D. V. (Eds.) (2003). Soil biological fertility: a key to sustainable land use in agriculture. Springer Science \& Business Media. http://www.agric.ns w.gov.au/reader/soil-biology.

2. Anonymous (2020). Statistical Handbook, Mizoram 2010. 
Government of Mizoram, Mizoram, Aizawl,186.

3. Babiker, B. M., Ahmed, M. A. E., \& Ibrahim, H. M. (2017) Isolation \& identification of catalase producing Bacillus spp: A comparative study. Int. J. Adv. Res., 4, 1206-1211.

4. Bani, A., Pioli, S., Ventura, M., Panzacchi, P., Borruso, L., Tognetti, R., Tonon, G., \& Brusetti, L. (2018). The role of microbial community in the decomposition of leaf litter and deadwood. Applied Soil Ecology, 126, 75-84. https:// doi.org/10.1016/j.apsoil.2018.02.017

5. Bauder, J. (2000). Cereal crop residues and plant nutrients. Montana State University Communications Services.

6. Bergey, D.H. \& Holt, J.G. (2000). Bergey's manual of determinative bacteriology. Lippincott Williams and Wilkins, Philadelphia.

7. Cornwell, W.K., Cornelissen, J.H., Amatangelo, K., Dorrepaal, E., Eviner, V.T., Godoy, O., Hobbie, S.E., Hoorens, B., Kurokawa, H., Pérez-Harguindeguy, N. \& Quested, H.M. (2008). Plant species traits are the predominant control on litter decomposition rates within biomes worldwide. Ecology Letters, 11(10), 1065-1071.

8. Debi, C., \& Parkash, V. (2017). Comparative Soil Nutrient Status and Microbiota Associated in the Rhizosphere of Oroxylum indicum growing in Different Natural Habitat in North East India. International Journal of Current Microbiology and Applied Sciences, 6(12), 2627-2640. https:// doi.org/10.20546/ijcmas.2017.612.304

9. Eida, M. F., Nagaoka, T., Wasaki, J., \& Kouno, K. (2009). Isolation and characterization of cellulose-decomposing bacteria inhabiting sawdust and coffee residue composts. Microbes and Environments, 1202170356-1202170 356. doi:10.1264/jsme2.ME11299

10. Eisenberg, T., Nicklas, W., Mauder, N., Rau, J., Contzen, M., Semmler, T., Hofmann, N., Aledelbi, K. \& Ewers, C. (2015). Phenotypic and genotypic characteristics of members of the genus Streptobacillus. PLoS One, 10(8), e0134312.

11. Fosu, M., Kühne, R. F., \& Vlek, P. L. G. (2007). Mineralization and microbial biomass dynamics during decomposition of four leguminous residues. Journal of Biological Sciences, 7(4), 632-637.

12. Ghorbani-Nasrabadi, R., Greiner, R., Alikhani, H. A., Hamedi, J., \& Yakhchali, B. (2013). Distribution of actinomycetes in different soil ecosystems and effect of media composition on extracellular phosphatase activity. Journal of Soil Science and Plant Nutrition, 13(1), 223-236. http:// dx.doi.org/10.4067/S0718-95162013005000020

13. Gilman, J. (1957). A manual of soil fungi. Soil Science, 84 (2), 183.

14. Giudice, M. C., Reis-Menezes, A. A., Rittner, G. M. G., Mota, A. J., \& Gambale, W. (2012). Isolation of Microsporum gypseum in soil samples from different geographical regions of Brazil, evaluation of the extracellular proteolytic enzymes activities (keratinase and elastase) and molecular sequencing of selected strains. Brazilian Journal of Microbiology, 43, 895-902. https://doi.org/10.1590/ S1517-83822012000300007" It "_blank" https://doi.or g/1 0.1590/S1517-83822012000300007

15. Grogan, P., Lalnunmawia, F., \& Tripathi, S.K. (2012). Shifting cultivation in steeply sloped regions: A review of management options and research priorities for Mizoram state, Northeast India. Agrofor. Syst, 84, 163-177.
16. Hauchhum, R., \& Tripathi, S. K. (2019). Carbon and nitrogen differences in rhizosphere soil of annual plants in abandoned lands following shifting agriculture in northeast India. Nutrient Cycling in Agroecosystems, 113(2), 157-166.

17. Herzog, C., Hartmann, M., Frey, B., Stierli, B., Rumpel, C., Buchmann, N., \& Brunner, I. (2019). Microbial succession on decomposing root litter in a drought-prone Scots pine forest. The ISME journal, 13(9), 2346-2362.

18. Hobbie, S. E., Eddy, W. C., Buyarski, C. R., Adair, E. C., Ogdahl, M. L., \& Weisenhorn, P. (2012). Response of decomposing litter and its microbial community to multiple forms of nitrogen enrichment. Ecological Monographs, 82 (3), 389-405. https://doi.org/10.1890/11-1600.1

19. Hoorman, J. J. (2010). Understanding soil microbes and nutrient recycling. Agriculture and natural resources. SAG, Ohio State University, USA.

20. Hoorman, J. J. (2011). The role of soil fungus. FactsheetAgriculture and natural resources. The Ohio State University Extension.

21. Jackson, M. L. (1973). Soil Chemical Analysis. Prentice Hall of India Ltd, New Delhi.

22. Kumar, B. S., Zothansanga, Senbagam, D., Kumar, N. S. \& Gurusubramanian, G. (2015). Practical Microbiology A Laboratory Manual. Panima Publishing Corporation, India.

23. Lalnunzira, C. \& Tripathi, S.K. (2018). Leaf and root production decomposition and carbon and nitrogen fluxes during stand development in tropical moist forests, Northeast India. Soil Research, 56(3), 306-317. https://doi.or $\mathrm{g} / 10.1071 / \mathrm{SR} 16265$

24. Li, Y. B., Li, Q., Yang, J. J., Lü, X. T., Liang, W. J., Han, X. G., \& Martijn Bezemer, T. (2017). Home-field advantages of litter decomposition increase with increasing $\mathrm{N}$ deposition rates: a litter and soil perspective. Functional Ecology, 31(9), 1792-1801. https://doi.org/10.1111/13652435.12863

25. Manpoong, C., De Mandal, S., Bangaruswamy, D. K., Perumal, R. C., Benny, J., Beena, P. S., \& Tripathi, S. K. (2020). Linking rhizosphere soil biochemical and microbial community characteristics across different land use systems in mountainous region in Northeast India. Meta Gene, 23, 100625.

26. Martin, J. P. (1950). Use of acid, rose bengal, and streptomycin in the plate method for estimating soil fungi. Soil Science, 69(3), 215-232.

27. Mason, C. (1977). Decomposition. The Camelot Press Ltd, Southampton.

28. McBrayer, J. F., \& CRoMACK Jr, K. E. R. M. I. T. (1980). Effect of snow-pack on oak-litter breakdown and nutrient release in a Minnesota forest ${ }^{\circ}$.

29. Momin, M. D., \& Tripathi, S. K. (2019). Actinomycetes from shifting cultivation (jhum) of Mizoram, Northeast India. Environment and Ecology, 37(3B), 1081-1085.

30. Momin, M. D., Singh, N. S., Kumar, A., \& Tripathi, S. K. (2021). Structural and functional characterization of rhizosphere actinomycetes of major crop plants under shifting cultivation practice in Northeast India. Vegetos, 1-9.

31. Munthali, M. G., Gachene, C. K. K., Karanja, N. K., \& Sileshi, G. W. (2013, October). Decomposition rates and nutrient release patterns of Tephrosia vogelii and Tephrosia candida residues in Malawi. In Joint Proceedings of the 27th Soil Science Society of East Africa and the 6th African Soil Science Society Conference. 
32. Nguyen, T. S., \& Thai, P. (1993). Tephrosia candida-a soil ameliorator plant in Vietnam. Contour (Jakarta), 5(1), 2728.

33. Olson, J. S. (1963). Energy storage and the balance of producers and decomposers in ecological systems. Ecology, 44(2), 322-331.

34. Pant, G., Prakash, A., Pavani, J. V. P., Bera, S., Deviram, G. V. N. S., Kumar, A., Panchpuri, M. \& Prasuna, R. G. (2015). Production, optimization and partial purification of protease from Bacillus subtilis. Journal of Taibah University for Science, 9(1), 50-55. https://doi.org/10.1016/j.jtusc i.2014.04.010

35. Pérez, J., Munoz-Dorado, J., De la Rubia, T. D. L. R., \& Martinez, J. (2002). Biodegradation and biological treatments of cellulose, hemicellulose and lignin: an overview. International Microbiology, 5(2), 53-63.

36. Quideau, S. A., Graham, R. C., Oh, S. W., Hendrix, P. F., \& Wasylishen, R. E. (2005). Leaf litter decomposition in a chaparral ecosystem, Southern California. Soil Biology and Biochemistry, 37(11), 1988-1998.

37. Raaijmakers, J. M., Paulitz, T. C., Steinberg, C., Alabouvette, C., \& Moënne-Loccoz, Y. (2009). The rhizosphere: a playground and battlefield for soil borne pathogens and beneficial microorganisms. Plant and soil, 321 (1), 341-361.

38. Rajagopal, S. V., Kumar, K. S., \& Sankar, A. U. (2007) Production and characterisation of cellulase by Streptobacillus species-APS -8. Journal of Pure and Applied Microbiology, 1(2), 231-236.

39. Scarascia-Mugnozza, G., De Angelis, P., Sabatti, M., Calfapietra, C., Ceulemans, R., Peressotti, A., \& Miglietta, F. (2000). A FACE experiment on short rotation, intensive poplar plantation: objective and experimental set up of POPFACE. Terrestrial Ecosystem Research in Europe: Successes, Challenges and Policy. Office for Official Publications of the European Communities, Luxembourg, 136-140.

40. Sethi, S., Datta, A., Gupta, B. L., \& Gupta, S. (2013). Optimization of cellulase production from bacteria isolated from soil. International Scholarly Research Notices, 2013. http://dx.doi.org/10.5402/2013/985685.
41. Singh, N. S., \& Tripathi, S. K. (2020). Litter mass loss rate changes as function of soil microbial diversity and litter chemical quality in tropical and sub-tropical forest of Mizoram: A microcosm study. Indian Journal of Ecology, 47(3), 792-798.

42. Swift, M. J., Heal, O. W., Anderson, J. M., \& Anderson, J. M. (1979). Decomposition in terrestrial ecosystems, 5. Univ of California Press.

43. Taylor, B. R., Parkinson, D., \& Parsons, W. F. (1989) Nitrogen and lignin content as predictors of litter decay rates: a microcosm test. Ecology, 70(1), 97-104. https:// www.jstor.org/stable/1938416.

44. Tripathi, S. K., \& Singh, K. P. (1992a). Abiotic and litter quality control during the decomposition of different plant parts in dry tropical bamboo savanna in India. Pedobiologia (Jena), 36(4), 241-256.

45. Tripathi, S. K., \& Singh, K. P. (1992b). Nutrient immobilization and release patterns during plant decomposition in a dry tropical bamboo savanna, India. Biology and Fertility of Soils, 14(3), 191-199.

46. Van Soest, P. J., \& Wine, R. H. (1968). Determination of lignin and cellulose in acid-detergent fiber with permanganate. Journal of the association of official analytical chemists, 51(4), 780-785. https://doi.org/10.1093/jaoac/5 1.4. 780

47. Villegas-Pangga, G., Blair, G., \& Lefroy, R. (2000). Measurement of decomposition and associated nutrient release from straw (Oryza sativa L.) of different rice varieties using a perfusion system. Plant and Soil, 223(1), 1-11.

48. Wang, W. J., Smith, C. J., \& Chen, D. (2004). Predicting soil nitrogen mineralization dynamics with a modified double exponential model. Soil Science Society of America Journal, 68(4), 1256-1265. https://doi.org/10.2136/sssaj2 004.1256

49. Wapongnungsang, H. R., \& Tripathi, S. K. (2017). Litter decomposition Vis-a-Vis carbon and nitrogen dynamics of Tephrosia candida components in different fallow periods following shifting cultivation in Mizoram. Indian Journal of Ecology, 44(4), 791-796. 